\title{
The genetic background of acromegaly
}

\author{
Mônica R. Gadelha ${ }^{1,2} \cdot$ Leandro Kasuki $^{1,2,3} \cdot$ Márta Korbonits $^{4}$
}

Published online: 4 February 2017

(C) The Author(s) 2017. This article is published with open access at Springerlink.com

\begin{abstract}
Acromegaly is caused by a somatotropinoma in the vast majority of the cases. These are monoclonal tumors that can occur sporadically or rarely in a familial setting. In the last few years, novel familial syndromes have been described and recent studies explored the landscape of somatic mutations in sporadic somatotropinomas. This short review concentrates on the current knowledge of the genetic basis of both familial and sporadic acromegaly.
\end{abstract}

Keywords Acromegaly $\cdot$ Genetic basis $\cdot$ Familial disease · AIP

\section{Introduction}

Acromegaly is caused by excess growth hormone (GH) secreted from the pituitary gland most often due to a somatotropinoma. While somatotropinomas are monoclonal tumors that occur sporadically in the vast majority of the patients, acromegaly can also be part of a familial disease.

Márta Korbonits

m.korbonits@qmul.ac.uk

1 Neuroendocrinology Research Center/Endocrine Section and Medical School - Hospital Universitário Clementino Fraga Filho, Universidade Federal do Rio de Janeiro, Rio de Janeiro, Brazil

2 Neuroendocrine Section - Instituto Estadual do Cérebro Paulo Niemeyer, Secretaria Estadual de Saúde do Rio de Janeiro, Rio de Janeiro, Brazil

3 Endocrine Unit, Hospital Federal de Bonsucesso, Rio de Janeiro, Brazil

4 Centre for Endocrinology, Barts and the London School of Medicine, Queen Mary University of London, Charterhouse Square, London EC1A 6BQ, UK
No exact data are available in what percentage of unselected acromegaly patients have a congenital (germline or mosaic) cause of their disease. We know, however, that almost $50 \%$ of childhood-onset cases leading to gigantism have a now identifiable genetic background $[1,2]$.

Tumor development is a complex multistep process influenced by genetic, epigenetic and environmental factors as well as by the tumor microenvironment. In this brief overview, we concentrate on the genetic basis of sporadic and familial acromegaly while refer to an excellent review regarding other molecular mechanisms [3].

Acromegaly can be part of a syndromic disease occurring concomitantly with other endocrine tumors, such as in MEN1, MEN4, Carney complex, McCune-Albright and SDHx-related pituitary adenomas (Table 1) or presents as part of familiar isolated pituitary adenoma (FIPA) in aryl hydrocarbon receptor interacting protein $(A I P)$ or GPR101 (G-protein coupled receptor 101) mutation positive and negative cases $[4,5]$.

\section{Familial isolated pituitary adenomas}

Familial isolated pituitary adenoma syndrome is the most common familial cause of acromegaly/gigantism, as available data suggest that syndromic familial acromegaly, due to Carney complex, MEN1, MEN4 and SDH-related syndromes, are less common [6-10].

FIPA families can be heterogeneous (when more than one type of pituitary adenoma is present in the same family) or homogeneous [11]. In our cohort of 216 FIPA families, $60 \%$ had at least one subject with GH excess $(92 \%$ of the 37 AIP mutation positive families and $53 \%$ of the 179 AIP mutation negative families). Twenty-eight percent of the whole cohort had homogenous GH FIPA ( $43 \%$ of the 


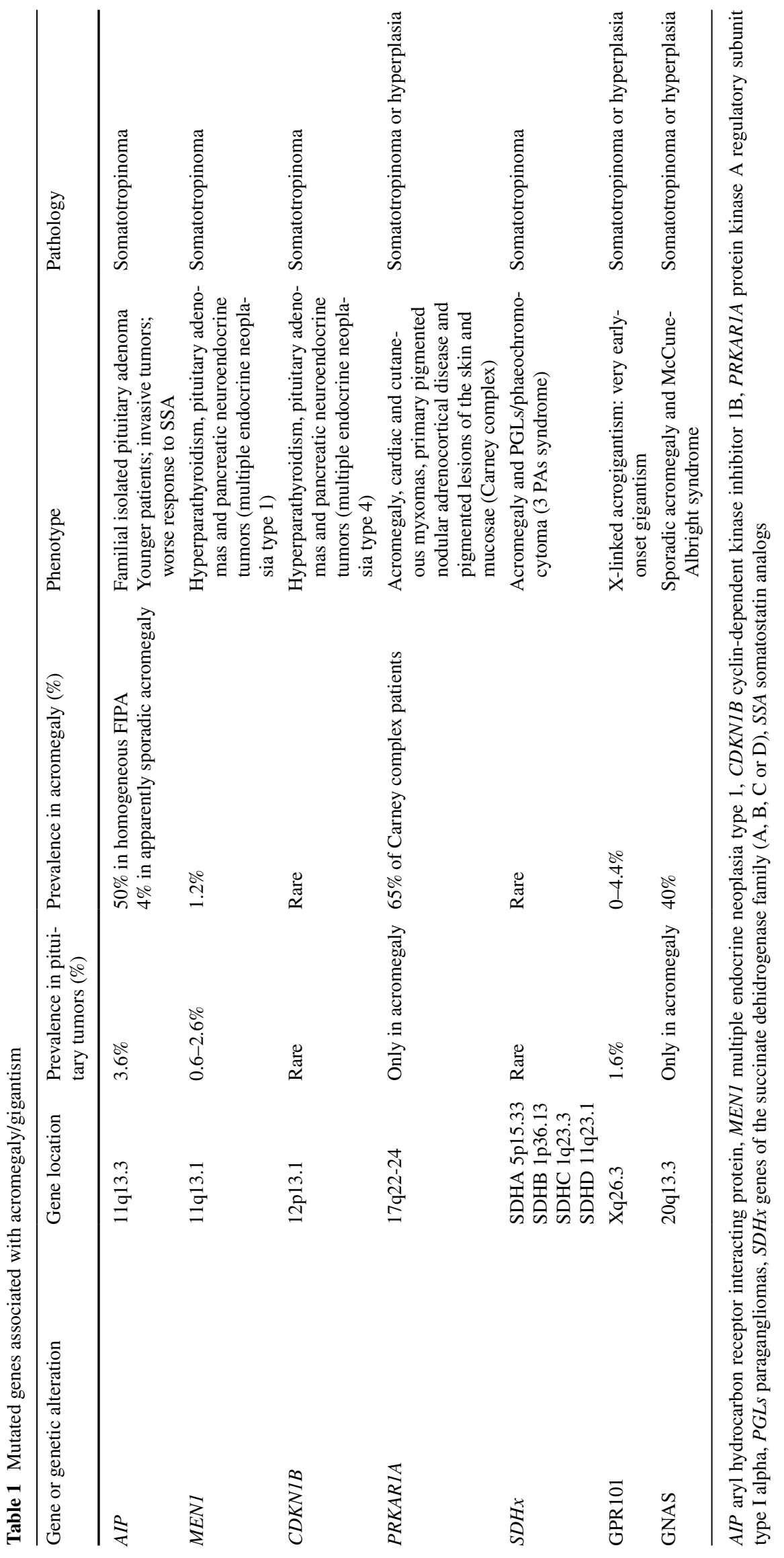


37 AIP mutation positive families and $24 \%$ of the 179 AIP negative families).

The genetic basis for the majority of FIPA cases is currently not known. A fifth of the families have germline mutations in the AIP gene [6, 12] and GPR101 mutations (duplications) have been described in two families [13] (Fig. 1).

\section{AIP}

Heterozygous loss-of-function AIP mutations predispose the appearance of young-onset pituitary adenomas with an incomplete (20-23\%) penetrance [23]. About 50\% of AIP mutations kindreds present as sporadic cases due to low penetrance rather than de novo mutations [6]. The prevalence of AIP mutations is doubled (36-40\%) when considering homogeneous acromegaly/gigantism FIPA families compared to the frequency in all the FIPA families. Somatotropinomas, with or without prolactin co-secretion, represent the most common AIP mutation positive adenoma type followed by prolactinomas (Fig. 1). A few clinically nonfunctioning adenomas have also been described but these usually show positive immunostaining for $\mathrm{GH}$ and prolactin [6]. A few ACTH- and a single TSH-secreting adenoma have also been described [24]. Somatotropinomas harboring AIP mutations are more frequently macroadenomas $(88 \%)$ with extrasellar extension, more frequent in younger patients ( $78 \%$ younger than $<30$ years) and present with a higher frequency of apoplexy especially in children [6, $12,25,26]$. A slight male preponderance has been shown earlier [12], but with extensive familial screening a more balanced picture is emerging [6]. Patients with AIP mutation show poor response to somatostatin receptor ligands (SRLs) [12]. There are two hypothesis to explain this poor response: (i) first-generation SRLs increase AIP expression and, in turn, this can upregulate the tumor suppressor zincfinger protein ZAC1 which has been previously linked to SRLs anti-proliferative effects [27]. Interestingly, sporadic somatotropinomas without AIP mutations with low AIP protein expression also have a poor response to first-generation SRLs [28, 29]. Therefore, the lack or low level of AIP via the lack of ZAC1 upregulation could explain the resistance to treatment with SRLs [4, 30]; (ii) another mechanism for SRLs resistance of AIP mutation positive cases could be the low level of inhibitory $G$ protein which has been identified both in embryonic fibroblast lacking AIP and human pituitary adenomas with AIP mutation [31].

The AIP gene is located at chromosome 11q13 and encodes a 330 amino acid protein suggested to be a tumor suppressor gene. AIP influences the cAMP pathway [32] via inhibitory G proteins (Goi2) [31], via phosphodiesterases [33, 34] and via interfering with downstream pathway of somatostatin receptors [30], but the exact mechanism how lack of AIP leads to somatotroph adenomas is unclear. Over $70 \%$ of pathogenic mutations identified to date lead to missing or truncated protein (frameshift, nonsense, small and large deletions, variants in the regulatory region with functional data on promoter activation supporting reduced activity), while missense mutations and in-frame small deletions and insertions can also occur mostly affecting the $\mathrm{C}$ terminal characteristic tetratricopeptide domains $[4,24,25]$. Separating pathogenic variants from benign polymorphisms can be challenging in some cases. Several AIP sequence variants were tested in vitro using two-hybrid assay between PDE4A5 and AIP to help to identify pathogenicity of some of the questionable AIP variants [25, 33]. There are a few mutational hotspots in the AIP gene: the most common one affects the Arg304 residue, while Arg81 and Arg271 have also been described in independent cohorts [35].

The type of AIP mutation can influence the phenotype, with patients harboring truncating mutations being younger at diagnosis than those harboring full-length mutated proteins [6]. Regarding mutant AIP proteins, it has been shown that many pathogenic missense AIP mutations have a significantly reduced stability in experimental conditions [36]. This suggests that the mechanism of lack of function in these cases may be the rapid degradation of the (probably) misfolded protein [36].

AIP mutations can also be identified in sporadic acromegaly cases [6, 37-41]. Considering patients without any age limitations, only about $4 \%$ of the apparently sporadic patients will harbor a germline AIP mutation [40]. However, this is more frequent in young patients, especially those harboring macroadenomas, being found in up to $13 \%$ of patients younger than 30 years of age and can be found in up to $33 \%$ of pediatric (18 years) patients [39, 42]. The lack of family history is due to the incomplete penetrance as only one de novo acromegaly case has been described to date [43].

In the presence of an AIP mutation in a patient with apparently sporadic acromegaly, screening of the firstdegree relatives for the mutation should be performed [44]. Family member screening of AIP carriers was shown to identify $24 \%$ of 'unaffected' carriers with biochemical or radiological abnormalities, and, interestingly, half of these actually had symptoms but did not previously seek medical attention. We need to be cautious, however, as, similar to MEN1 screening, the small non-functioning lesions in AIP mutation carrier subjects may represent incidentalomas. Considering the prevalence of germline AIP mutations in young patients with apparently sporadic pituitary tumors, while no formal guidelines exist, several groups recommend that screening for AIP mutations be performed in all patients diagnosed before 18 years of age and in patients 


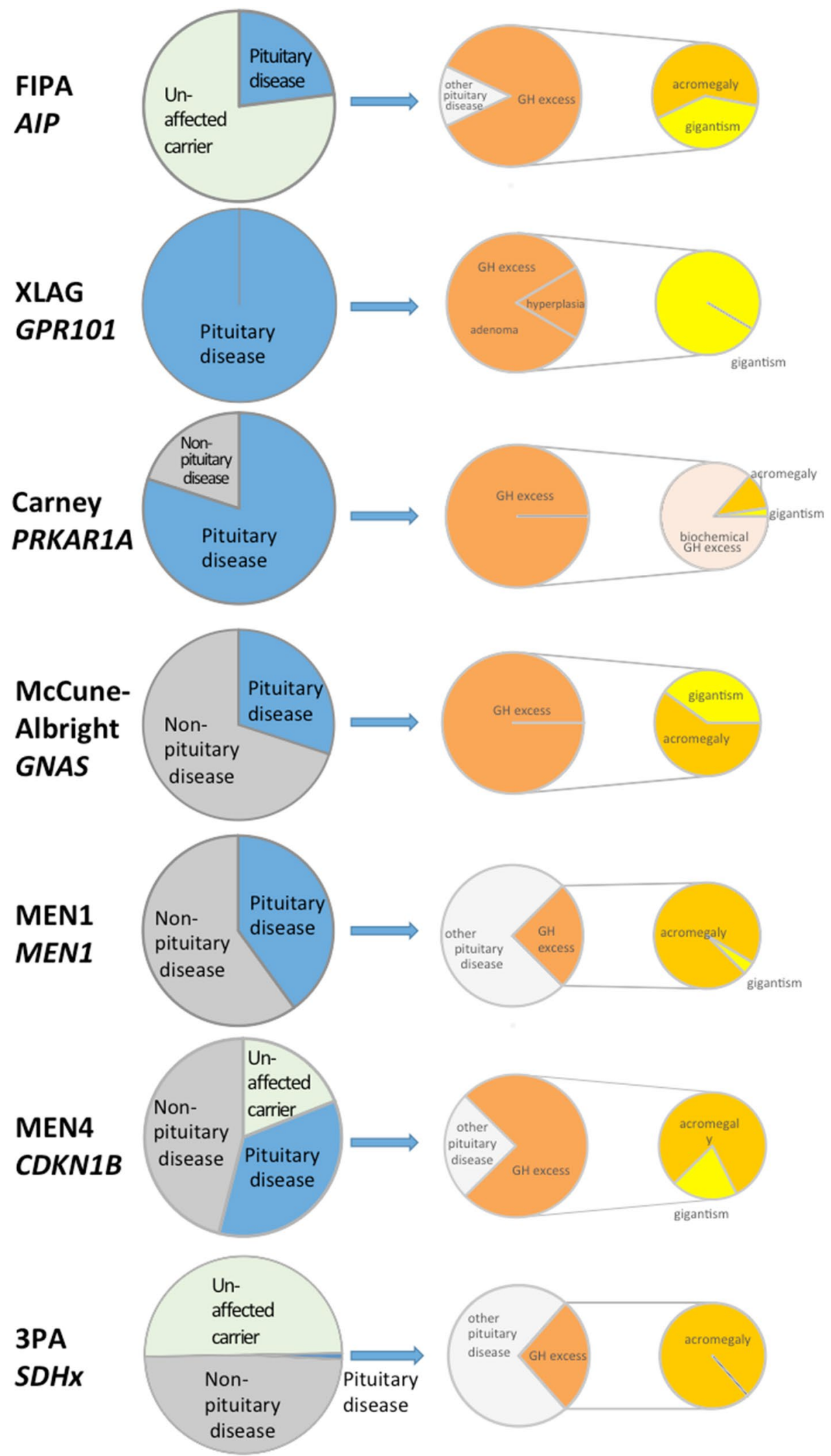


\Fig. 1 For each of the syndromes, the left pie represents the percentage of pituitary adenomas in patients with the disease. The middle pie represents the percentage of patients with GH excess and the right pie shows the proportion of patients with acromegaly or gigantism. AIP: 20 to $23 \%$ of gene carriers manifest the disease, all affected patients have a pituitary adenoma and $86 \%$ of these result in GH excess [6]. Overall $48 \%$ of $\mathrm{GH}$ excess patients have gigantism [6], but in a homogenous R304* cohort 58\% had gigantism [14] confirming that truncating mutation patients have lower age of onset of disease [6]. XLAG: All gene carriers develop pituitary disease, 83\% adenoma and $17 \%$ hyperplasia and all have gigantism [15]. Carney complex: $80 \%$ of gene carriers will have biochemical GH abnormality and $10 \%$ will manifest clinical acromegaly [16]. A few patient have been described with gigantism. McCune-Albright syndrome: $70 \%$ of gene carriers will have GH excess and $36 \%$ of these would have gigantism [17]. MEN1: $40 \%$ of MEN1 gene mutation carriers have a pituitary adenoma and $25 \%$ of these have acromegaly, with very few cases described in children $[18,19]$. We note, however, that in a systematic screening study [10] a large number of small NFPAs have been identified and the percentage of acromegaly is only $7 \%$ among the pituitary adenoma patients in this study. GHRH-secreting pancreas tumors can also lead to acomegaly or gigantism in MEN1 patients. MEN4: Among the very few patients and unaffected family members described with $C D K N 1 B$ mutation $4 / 5$ th of the patients were affected (this could be ascertainment bias and more data is needed to identify true penetrance), $63 \%$ of the affected subjects (30\% of all carriers) had pituitary disease and $2 / 3$ of these ( 5 cases) had GH excess with one of these having gigantism. Interestingly, in two of the five GH excess cases, the mutation was located in the 5'UTR (untranslated region) [20, 21]. 3PAs: As the penetrance of an abnormality in the various $S D H$ subtype mutation carriers can be different, we show here penetrance data $\sim 50 \%$ for $S D H B$ mutations. Among the affected subjects very low percentage of $S D H x$ carriers have a pituitary adenoma $(<1 \%)$. Out of 15 cases reviewed four $(28 \%)$ had acromegaly, none of them were childhood-onset [22]

harboring a macroadenoma diagnosed before 30 years of age $[24,40,44]$.

\section{X-linked acrogigantism (XLAG)}

Patients with very early-onset gigantism may harbor an unusual type of mutation, a microduplication of chromosome Xq26.3 (Fig. 1) [13]. The Xq26.3 region codes four genes, but only one of them, GPR101, coding for an orphan G-protein coupled receptor, was overexpressed in the patients with a microduplication of this region [13]. The causative role of this gene was reinforced by a case with typical phenotype but with a smaller microduplication only including the GPR101 gene [2]. Extensive search for Xq26.3 microduplication in pediatric or adult cases of $\mathrm{GH}$ excess could only identify this genetic abnormality in very early-onset (accelerated growth before the age of 5 years) gigantism cases. Altogether 31 patients have been reported to date, including two unrelated families and 26 sporadic cases [2, 13, 45-47]. The majority of the cases are females and harbor de novo mutations and penetrance is $100 \%$ based on available data. Sporadic male cases described to date harbor mosaic mutations [2, 45,
48]. Interestingly, diagnosis was challenging in a case of a 4 year old boy with pituitary hyperplasia and gigantism, where germline DNA showed no detectable duplication with CGH array and droplet PCR was not conclusive. The diagnosis was finally made using DNA derived from pituitary tissue and skin biopsy showing the typical GPR101 duplication [48]. Patients have a median age of disease onset of 1.0 year (ranging from 0.5 to 2.0 years), and were younger than those gigantism patients who did not present the microduplication (median age of disease onset of 16.0 years, ranging from 5.0 to 18.0 years) $[1,13]$. XLAG patients represent the second largest group of patients with childhood-onset acromegaly, after AIP mutation positive patients and there is no phenotypic difference between mosaic or germline XLAG cases [1, 2, 45].

The GPR101 gene variant p.E308D was originally suggested to play a role in acromegaly pathogenesis (11 out of 248 patients with acromegaly) (4.4\%) [13], but extensive data from different laboratories cannot confirm these data. A large study including 766 patients with apparently sporadic pituitary tumors found a frequency of $1.6 \%$ of germline GPR101 variants (three patients with acromegaly, two with Cushing`s disease and one with a nonfunctioning pituitary adenomas) $[49,50]$. The observed allele frequency (0.49) was not different form the frequency present in the general population [0.69, Exome Aggregation Consortium (ExAc) database (http://exac.broadinstitute. org)] in another study which included 395 leukocyte- and 193 somatotropinoma-derived samples [2]. A recent Italian study found no germline GPR101 variants in a cohort of 215 patients with $\mathrm{GH}$-secreting adenomas [38].

\section{Multiple endocrine neoplasia types 1 and 4 (MEN1 and MEN4)}

Acromegaly can occur in the setting of a multiple endocrine neoplasia. In multiple endocrine neoplasia type 1 (MEN1), pituitary adenomas are associated with hyperparathyroidism and neuroendocrine tumors of the pancreas [19]. Germline mutations in the MEN1 gene are found in $80-90 \%$ of the probands with familial MEN1 and in approximately $65 \%$ of the patients with sporadic MEN1 [19, 51, 52]. MEN1 mutations were described in $1.2 \%$ of sporadic acromegaly patients younger than 30 years of age [51].

Primary hyperparathyroidism is the most common component of MEN1, being observed in over $90 \%$ of the cases. Pituitary tumors occur in 38\% (15-50\%) of the cases presenting with pituitary disease [10, 53, 54], with prolactinomas being the most frequent $(60 \%)$ and somatotropinomas being the second most common $(25 \%)$ (Fig. 1) [19]. Interestingly, a prospective screening study found different proportions of pituitary disease subtypes 
with significantly higher number non-functioning adenomas. These differences might be explained by the different strategies used to collect the data (spontaneous presentation vs. clinical screening) [10] and it is unclear what percentage of these often small non-functioning adenomas represent, in fact, incidentalomas. Pituitary tumors in MEN1 occur more frequently in women, prolactinomas are more common in younger patients and are often invasive macroadenomas. In MEN1 patients with acromegaly, the diagnosis is usually made after 40 years of age [19]. Although three patients with MEN1-associated acromegaly are reported to be treated medically, no data are available of their SRLs responsiveness [8]. In MEN1 patients with acromegaly and enlarged pituitary gland with no discernable pituitary adenoma, a GHRH-secreting neuroendocrine tumor, typically arising from the pancreas should also be considered [55]. Co-existance of acromegaly due to GHRH-secreting neuroendocrine tumor and a prolactinoma has also been described in MEN1 syndrome, representing a significant diagnostic challange [56]. Circulating GHRH measurement is now routinely available in reference laboratories [55].

The tumor suppressor gene MEN1 is located at chromosome 11q13 coding for the protein menin. MEN1 exhibits an autosomal dominant inheritance pattern [19, 57]. To date, the exact mechanism by which inactivating MEN1 mutation leads to tumorigenesis is unknown, but menin has been shown to influence numerous relevant processes such as the cell cycle, cell division, genome stability and transcriptional regulation [57]. The last detailed review identified 1133 different germline and 203 somatic mutations without typical hotspots [51], although codons 139, in exon 2 , and 418 in exon 9, were affected by the highest number of mutations (seven different mutations) [51]. Regarding the type of mutations, $26 \%$ were missense mutations, $14 \%$ were nonsense mutations, $42 \%$ were frameshift insertions or deletions, $5.5 \%$ were in-frame insertions or deletions, $10 \%$ were splice site mutations and $2.5 \%$ were large deletions [51, 52]. Screening for MEN1 mutations in patients with acromegaly should be considered in the presence of other features of the syndrome or in the presence of a family history of MEN1 $[57,58]$.

Rarely patients with MEN1 phenotype, but without MEN1 mutations, harbor mutations in the cyclin-dependent kinase inhibitor 1B $(C D K N 1 B)$ gene coding for $\mathrm{p} 27^{\mathrm{kip} 1}$ protein $[9,59]$. This syndrome is named multiple endocrine neoplasia type 4 (MEN4) and only nine cases have been described with pituitary adenomas. Five of the nine reported MEN4-related pituitary disease is acromegaly (Fig. 1). Therefore, in an acromegaly/gigantism patient with features of the MEN1 syndrome but without MEN1 mutations, screening for $C D K N 1 B$ mutations is indicated [58].

\section{Carney complex}

Carney complex (CNC) is a syndrome characterized by the presence of acromegaly (10-12\%), cardiac and cutaneous myxomas, primary pigmented nodular adrenocortical disease (PPNAD) and pigmented lesions of the skin and mucosae (can vary from lentigines to blue nevi) [16]. CNC presents as familial disease in $70 \%$ of the cases and is inherited in an autosomal dominant manner with an overall full penetrance. GH excess is present in $80 \%$ of the cases and is mainly consequence of a pituitary somatotroph hyperplasia and not due to a pituitary adenoma (Fig. 1) [16].

The cause of the majority of CNC cases is a mutation in the PRKARIA gene, coding for the regulatory subunit type I alpha of the protein kinase A, located at chromosome $17 q 24[60,61]$. A second genetic locus associated with $\mathrm{CNC}$ has been described in chromosome region $2 \mathrm{p} 16$, but the specific genetic defect has not been elucidated $[16,61]$. A single case of gene duplication affecting the catalytic B subunit of PKA has also been described [62].

\section{Acromegaly and paraganglioma/phaeochromocytoma syndrome}

The coexistence of acromegaly with paragangliomas (PGLs) or phaeochromocytomas has been described since 1952 [63]. As they are both rare tumors, the occurrence of both in the same patient can be coincidental but attention in the recent years has been given for a possibly common genetic basis, for the recently named "3PAs" syndrome (paragangliomas, phaeochromocytomas and pituitary adenomas) [64].

Considering that mutations in the genes coding the succinate dehydrogenase (SDH) complex are the most common genetic causes of PGLs/phaeochromocytomas it has been studied in the cases of 3PAs [22, 64, 65]. Following description of a succinate dehydrogenase type B (SDHB) mutation positive patient with a pituitary adenoma [66] and SDHB mutation positive familial PGLs and macroprolactinomas [67], somatotroph adenomas have also been associated with $S D H$ mutations (SDHA, SDHB and SDHD) [64, $65,68,69]$.

In some cases, the 3PAs syndrome occurs in the absence of mutations in the SDH complex genes [22]. Mutations in genes causing other familial syndromes may be found and, actually, there is a reported case with mutation in the MEN1 and other case with mutation in the RET gene [65, 70].

\section{McCune-Albright syndrome}

Patients with McCune-Albright syndrome may present as sporadic acromegaly or gigantism. They harbor a mosaic 
mutation in the GNAS gene coding for the alpha-subunit of the G-stimulatory protein (Gos). McCune-Albright syndrome characterized by the development of polyostotic fibrous dysplasia, café-au-lait spots and endocrine hyperfunction, including precocious puberty, thyrotoxicosis due to autonomous thyroid nodules, Cushing`s syndrome (caused by nodular adrenal hyperplasia) and GH excess or manifest acromegaly/gigantism [71, 72]. Excess of GH, often with prolactin co-secretion, is observed in approximately $20 \%$ of the cases. In the majority of the cases pituitary hyperfunction is caused by pituitary hyperplasia and not by an adenoma [72]. The diagnosis of McCuneAlbright syndrome, thus, should be suspected in acromegaly/gigantism patients with other features of the syndrome.

The GNAS gene is located at chromosome 20q13.3. Mutations in the GNAS gene have been described more frequently at codon 201 (Arg201 for Cys or His or Ser) than at codon 227 (Gln227 for Arg or Leu) [73-75]. These mutations lead to loss of GTPase activity of the G-stimulatory protein alpha subunit while leaving the adenyl cyclase stimulatory activity intact. The resulting constitutive activation and increased intracellular cAMP levels lead to somatotroph proliferation/hyperplasia and GH hypersecretion [76].

\section{GH excess in neurofibromatosis type 1}

GH excess has been described in both pediatric and adult patients with neurofibromatosis leading to gigantism or acromegaly ([77-80] and references within). Although most cases are associated with optic gliomas and no pituitary tumors, a few has been described with GH positive pituitary adenomas and it is unclear if the latter ones are pure coincidences or not.

\section{Somatic changes in somatotropinomas}

The most common somatic mutation in acromegaly are the activating mutations of the GNAS gene [76], with a frequency of about $40 \%$ (ranging from 10 to $50 \%$ depending on the ethnical background) [73, 74, 81-83]. Somatic GNAS mutations are found with equal frequency in both sexes and are more frequent in tumors from older patients $[73,83]$. They are also more common in smaller tumors that secrete higher GH levels and are associated with a densely granulated pattern in the histopathology analysis $[75,84]$.

Some studies suggest that tumors harboring a GNAS mutation present a better response to first-generation SRLs, but this finding is not homogeneous in the literature [74, 83-85]. Recently, a meta-analysis including eight studies and 315 patients concluded that patients with a GNAS mutation present a higher reduction of $\mathrm{GH}$ levels during the acute octreotide suppression test [75]. However, studies addressing the response to long-term SRLs treatment present conflicting results [74, 84].

To identify further somatic mutations in sporadic somatotroph adenomas exome [83, 86] and whole genome sequencing studies were performed [87]. Välimäki et al. performed a whole-genome sequencing and single-nucleotide polymorphism (SNP) array in 12 fresh-frozen somatotropinomas and in the leucocyte DNA of the corresponding patients [87]. The whole-genome sequencing showed an average of 129 somatic nucleotide variants (SNV), with an average of $2.3 \mathrm{SNV}$ per tumor. However, the only recurrent somatic events were GNAS mutations and shared chromosome losses (chromosomes 1, 6, 13, 14, 15, 16, 18 and 22). No novel recurrent mutated genes were identified. In agreement with these findings, Ronchi et al. performed a nextgeneration whole-exome sequencing in 36 sporadic somatotropinomas, identifying a median of three mutations per sample [86]. Again, the only recurrent somatic mutation observed was in the GNAS gene (31.4\% of the cases). More recently, Song et al. performed whole-exome sequencing and copy number analysis in 125 pituitary adenomas, including 20 somatotropinomas [83]. They observed GNAS mutations in 55\% of the tumors. Interestingly, copy number variation was also found affecting the chromosome 20q13.3 region, where the GNAS gene is located, in $8 / 20$ samples, 5 of those also had a single nucleotide GNAS mutation. However, the 20q13.33 locus contains synaptonemal complex protein 2 (SYCP2), a cohesion complex gene, while other cohesion complex genes were also found amplified in somatotroph adenomas:SYPCl on chromosome 1p13.2 was amplified in 11/20 somatotroph samples and RAD21 cohesin complex component like 1 (RAD21LI) on chromosome 20p13 was amplified in 4/20. While data from independent cohort and functional characterization is needed, these results raise the possibility that cohesion complex might play a role in pituitary adenoma genesis [88].

These studies altogether identified three possible pathways involved in somatotroph tumorigenesis: the cAMP, the calcium-channel signaling and the cohesin pathways. In the study by Ronchi et al., seven genes involved in the cAMP signaling pathway were affected in 14 of the 36 samples and eight samples harbored variants in genes involved in the calcium signaling or metabolism [86]. In the study by Välimäki et al., five genes involved in cAMP or calcium-related signaling pathways were found to be mutated [87]. As an increase in cAMP levels is associated with an increase in cytosolic free calcium and this triggers the GH secretion, it is probably that genetic and/ or epigenetic alterations in these pathways lead to the development of somatotropinomas. In the Song et al. study 13/20 samples had changes in the cohesion pathway members [83]. 


\section{Conclusion}

Acromegaly is caused in the majority of the cases by a sporadic somatotropinoma and rarely by pituitary hyperplasia. In $95 \%$ of the cases it occurs sporadically but almost $50 \%$ of the childhood-onset cases have an identifiable genetic background, most commonly AIP or GPR101 mutations. Acromegaly is one of the most frequent pituitary adenoma types which occur in a familial setting most commonly due to AIP mutations. Genetic screening has been shown to identify family members in an earlier stage of the disease which is predicted to lead to better long-term outcome. Therefore genetic testing and counselling of family members will improve the long-term management of this disease.

Acknowledgements The authors are grateful to Pedro Marques and Laura Hernández-Ramírez for the help collecting data for this review.

Funding The research has not received funding from any organization or company and was sponsored by the authors themselves.

\section{Compliance with ethical standards}

Conflict of interest MRG has received unrestricted research grants and lecture fees from Novartis, Ipsen and Pfizer, has participated on advisory boards of Novartis and Ionis and is principal investigator in clinical trials by Novartis and Ipsen. MK received grant funding from Pfizer and Novartis and is a member of the advisory board of Pfizer and Æterna Zentaris. The other author has no conflict of interest.

Open Access This article is distributed under the terms of the Creative Commons Attribution 4.0 International License (http:// creativecommons.org/licenses/by/4.0/), which permits unrestricted use, distribution, and reproduction in any medium, provided you give appropriate credit to the original author(s) and the source, provide a link to the Creative Commons license, and indicate if changes were made.

\section{References}

1. Rostomyan L, Daly AF, Petrossians P, Nachev E, Lila AR, Lecoq AL, Lecumberri B, Trivellin G, Salvatori R, Moraitis AG, Holdaway I, Kranenburg-van Klaveren DJ, Chiara Zatelli M, Palacios N, Nozieres C, Zacharin M, Ebeling T, Ojaniemi M, Rozhinskaya L, Verrua E, Jaffrain-Rea ML, Filipponi S, Gusakova D, Pronin V, Bertherat J, Belaya Z, Ilovayskaya I, SahnounFathallah M, Sievers C, Stalla GK, Castermans E, Caberg JH, Sorkina E, Auriemma RS, Mittal S, Kareva M, Lysy PA, Emy P, De Menis E, Choong CS, Mantovani G, Bours V, De Herder W, Brue T, Barlier A, Neggers SJ, Zacharieva S, Chanson P, Shah NS, Stratakis CA, Naves LA, Beckers A (2015) Clinical and genetic characterization of pituitary gigantism: an international collaborative study in 208 patients. Endocr Relat Cancer 22(5):745-757. doi:10.1530/ERC-15-0320

2. Iacovazzo D, Caswell R, Bunce B, Jose S, Yuan B, HernandezRamirez LC, Kapur S, Caimari F, Evanson J, Ferrau F, Dang MN, Gabrovska P, Larkin SJ, Ansorge O, Rodd C, Vance ML,
Ramirez-Renteria C, Mercado M, Goldstone AP, Buchfelder M, Burren CP, Gurlek A, Dutta P, Choong CS, Cheetham T, Trivellin G, Stratakis CA, Lopes MB, Grossman AB, Trouillas J, Lupski JR, Ellard S, Sampson JR, Roncaroli F, Korbonits M (2016) Germline or somatic GPR101 duplication leads to X-linked acrogigantism: a clinico-pathological and genetic study. Acta Neuropathol Commun 4(1):56. doi:10.1186/s40478-016-0328-1

3. Sapochnik M, Nieto LE, Fuertes M, Arzt E (2016) Molecular mechanisms underlying pituitary pathogenesis. Biochem Genet 54(2):107-119. doi:10.1007/s10528-015-9709-6

4. Gadelha MR, Kasuki L, Korbonits M (2013) Novel pathway for somatostatin analogs in patients with acromegaly. Trends Endocrinol Metab 24:238-246. doi:10.1016/j.tem.2012.11.007

5. Chahal HS, Chapple JP, Frohman LA, Grossman AB, Korbonits M (2010) Clinical, genetic and molecular characterization of patients with familial isolated pituitary adenomas (FIPA). Trends Endocrinol Metab 21:419-427. doi:10.1016/j.tem.2010.02.007

6. Hernández-Ramírez LC, Gabrovska P, Dénes J, Stals K, Trivellin G, Tilley D, Ferraù F, Evanson J, Ellard S, Grossman AB, Roncaroli F, Gadelha MR, Korbonits M, Consortium TIF (2015) Landscape of familial isolated and young-onset pituitary adenomas: prospective diagnosis in AIP mutation carriers. J Clin Endocrinol Metab 100(9):E1242-E1254. doi:10.1210/ jc.2015-1869

7. Stratakis CA, Kirschner LS, Carney JA (2001) Clinical and molecular features of the Carney complex: diagnostic criteria and recommendations for patient evaluation. J Clin Endocrinol Metab 86(9):4041-4046

8. Verges B, Boureille F, Goudet P, Murat A, Beckers A, Sassolas G, Cougard P, Chambe B, Montvernay C, Calender A (2002) Pituitary disease in MEN type 1 (MEN1): data from the FranceBelgium MEN1 multicenter study. J Clin Endocrinol Metab 87(2):457-465

9. Pellegata NS, Quintanilla-Martinez L, Siggelkow H, Samson E, Bink K, Hofler H, Fend F, Graw J, Atkinson MJ (2006) Germline mutations in p27Kip1 cause a multiple endocrine neoplasia syndrome in rats and humans. Proc Natl Acad Sci USA 103(42):15558-15563

10. de Laat JM, Dekkers OM, Pieterman CR, Kluijfhout WP, Hermus AR, Pereira AM, van der Horst-Schrivers AN, Drent ML, Bisschop PH, Havekes B, de Herder WW, Valk GD (2015) Longterm natural course of pituitary tumors in patients with MEN1: results from the DutchMEN1 study group (DMSG). J Clin Endocrinol Metab 100(9):3288-3296. doi:10.1210/JC.2015-2015

11. Daly AF, Jaffrain-Rea ML, Ciccarelli A, Valdes-Socin H, Rohmer V, Tamburrano G, Borson-Chazot C, Estour B, Ciccarelli E, Brue T, Ferolla P, Emy P, Colao A, De Menis E, Lecomte P, Penfornis F, Delemer B, Bertherat J, Wemeau JL, de Herder WW, Archambeaud F, Stevenaert A, Calender A, Murat A, Cavagnini F, Beckers, A (2006) Clinical characterization of familial isolated pituitary adenomas. J Clin Endocrinol Metab 91(9):3316-3323

12. Daly AF, Tichomirowa MA, Petrossians P, Heliovaara E, Jaffrain-Rea ML, Barlier A, Naves LA, Ebeling T, Karhu A, Raappana A, Cazabat L, De ME, Montanana CF, Raverot G, Weil RJ, Sane T, Maiter D, Neggers S, Yaneva M, Tabarin A, Verrua E, Eloranta E, Murat A, Vierimaa O, Salmela PI, Emy P, Toledo RA, Sabate MI, Villa C, Popelier M, Salvatori R, Jennings J, Longas AF, Labarta Aizpun JI, Georgitsi M, Paschke R, Ronchi C, Valimaki M, Saloranta C, De HW, Cozzi R, Guitelman M, Magri F, Lagonigro MS, Halaby G, Corman V, Hagelstein MT, Vanbellinghen JF, Barra GB, Gimenez-Roqueplo AP, Cameron FJ, Borson-Chazot F, Holdaway I, Toledo SP, Stalla GK, Spada A, Zacharieva S, Bertherat J, Brue T, Bours V, Chanson P, Aaltonen LA, Beckers A (2010) Clinical characteristics and therapeutic responses in patients with germ-line AIP mutations and 
pituitary adenomas: an international collaborative study. J Clin Endocrinol Metab 95(11):E373-E383. doi:10.1210/jc.2009-2556

13. Trivellin G, Daly AF, Faucz FR, Yuan B, Rostomyan L, Larco DO, Schernthaner-Reiter MH, Szarek E, Leal LF, Caberg JH, Castermans E, Villa C, Dimopoulos A, Chittiboina P, Xekouki P, Shah N, Metzger D, Lysy PA, Ferrante E, Strebkova N, Mazerkina N, Zatelli MC, Lodish M, Horvath A, de Alexandre RB, Manning AD, Levy I, Keil MF, Sierra MD, Palmeira L, Coppieters W, Georges M, Naves LA, Jamar M, Bours V, Wu TJ, Choong CS, Bertherat J, Chanson P, Kamenicky P, Farrell WE, Barlier A, Quezado M, Bjelobaba I, Stojilkovic SS, Wess J, Costanzi S, Liu P, Lupski JR, Beckers A, Stratakis CA (2014) Gigantism and acromegaly due to Xq26 microduplications and GPR101 mutation. N Engl J Med 371:2363-2374. doi:10.1056/ NEJMoa1408028

14. Radian S, Diekmann Y, Gabrovska P, Holland B, Bradley L, Wallace H, Stals K, Bussell AM, McGurren K, Cuesta M, Ryan AW, Herincs M, Hernandez-Ramirez LC, Holland A, Samuels J, Aflorei ED, Barry S, Denes J, Pernicova I, Stiles CE, Trivellin G, McCloskey R, Ajzensztejn M, Abid N, Akker SA, Mercado M, Cohen M, Thakker RV, Baldeweg S, Barkan A, Musat M, Levy M, Orme SM, Unterlander M, Burger J, Kumar AV, Ellard S, McPartlin J, McManus R, Linden GJ, Atkinson B, Balding DJ, Agha A, Thompson CJ, Hunter SJ, Thomas MG, Morrison PJ, Korbonits M (2017) Increased population risk of AIP-related acromegaly and gigantism in Ireland. Hum Mutat 38(1):78-85. doi:10.1002/humu.23121

15. Iacovazzo D, Korbonits M (2016) Gigantism: X-linked acrogigantism and GPR101 mutations. Growth Horm IGF Res. doi:10.1016/j.ghir.2016.09.007

16. Correa R, Salpea P, Stratakis CA (2015) Carney complex: an update. Eur J Endocrinol 173(4):M85-97. doi:10.1530/ EJE-15-0209

17. Salenave S, Boyce AM, Collins MT, Chanson P (2014) Acromegaly and McCune-Albright syndrome. J Clin Endocrinol Metab 99(6):1955-1969. doi:10.1210/jc.2013-3826

18. Trouillas J, Labat-Moleur F, Sturm N, Kujas M, Heymann MF, Figarella-Branger D, Patey M, Mazucca M, Decullier E, Verges B, Chabre O, Calender A (2008) Pituitary tumors and hyperplasia in multiple endocrine neoplasia type 1 syndrome (MEN1): a case-control study in a series of 77 patients versus 2509 nonMEN1 patients. Am J Surg Pathol 32(4):534-543. doi:10.1097/ PAS.0b013e31815ade45

19. Thakker RV (2014) Multiple endocrine neoplasia type 1 (MEN1) and type 4 (MEN4). Mol Cell Endocrinol 386(1-2):2-15. doi:10.1016/j.mce.2013.08.002

20. Occhi G, Regazzo D, Trivellin G, Boaretto F, Ciato D, Bobisse S, Ferasin S, Cetani F, Pardi E, Korbonits M, Pellegata NS, Sidarovich V, Quattrone A, Opocher G, Mantero F, Scaroni C (2013) A novel mutation in the upstream open reading frame of the CDKN1B gene causes a MEN4 phenotype. PLoS Genet 9(3):e1003350. doi:10.1371/journal.pgen.1003350 pii]

21. Sambugaro S, Di RM, Ambrosio MR, Pellegata NS, Bellio M, Guerra A, Buratto M, Foschini MP, Tagliati F, Degli UE, Zatelli MC (2015) Early onset acromegaly associated with a novel deletion in CDKN1B 5'UTR region. Endocr. doi:10.1007/ s12020-015-0540-y

22. O'Toole SM, Denes J, Robledo M, Stratakis CA, Korbonits M (2015) 15 YEARS OF PARAGANGLIOMA: The association of pituitary adenomas and phaeochromocytomas or paragangliomas. Endocr Relat Cancer 22(4):T105-122. doi:10.1530/ ERC-15-0241

23. Vierimaa O, Georgitsi M, Lehtonen R, Vahteristo P, Kokko A, Raitila A, Tuppurainen K, Ebeling TM, Salmela PI, Paschke R, Gundogdu S, De Menis E, Makinen MJ, Launonen V, Karhu A, Aaltonen, L.A (2006) Pituitary adenoma predisposition caused by germline mutations in the AIP gene. Science 312(5777):1228-1230. doi:10.1126/science. 1126100

24. Beckers A, Aaltonen LA, Daly AF, Karhu A (2013) Familial isolated pituitary adenomas (FIPA) and the pituitary adenoma predisposition due to mutations in the aryl hydrocarbon receptor interacting protein (AIP) gene. Endocr Rev 34(2):239-277. doi:10.1210/er.2012-1013

25. Igreja S, Chahal HS, King P, Bolger GB, Srirangalingam U, Guasti L, Chapple JP, Trivellin G, Gueorguiev M, Guegan K, Stals K, Khoo B, Kumar AV, Ellard S, Grossman AB, Korbonits M (2010) Characterization of aryl hydrocarbon receptor interacting protein (AIP) mutations in familial isolated pituitary adenoma families. Hum Mutat 31(8):950-960. doi:10.1002/humu.21292

26. Leontiou CA, van der Gueorguiev J, Quinton R, Lolli F, Hassan S, Chahal HS, Igreja SC, Jordan S, Rowe J, Stolbrink M, Christian HC, Wray J, Bishop-Bailey D, Berney DM, Wass JA, Popovic V, Ribeiro-Oliveira A Jr, Gadelha MR, Monson JP, Akker SA, Davis JR, Clayton RN, Yoshimoto K, Iwata T, Matsuno A, Eguchi K, Musat M, Flanagan D, Peters G, Bolger GB, Chapple JP, Frohman LA, Grossman AB, Korbonits M (2008) The role of the aryl hydrocarbon receptor-interacting protein gene in familial and sporadic pituitary adenomas. J Clin Endocrinol Metab 93(6):2390-2401. doi:10.1210/jc.2007-2611

27. Theodoropoulou M, Tichomirowa MA, Sievers C, Yassouridis A, Arzberger T, Hougrand O, Deprez M, Daly AF, Petrossians P, Pagotto U, Beckers A, Stalla GK (2009) Tumor $\mathrm{ZAC} 1$ expression is associated with the response to somatostatin analog therapy in patients with acromegaly. Int J Cancer 125(9):2122-2126

28. Kasuki L, Vieira NL, Wildemberg LE, Colli LM, De CM, Takiya CM, Gadelha MR (2012) AIP expression in sporadic somatotropinomas is a predictor of the response to octreotide LAR therapy independent of SSTR2 expression. Endocr Relat Cancer 19(3):L25-L29. doi:10.1530/ERC-12-0020

29. Jaffrain-Rea ML, Rotondi S, Turchi A, Occhi G, Barlier A, Peverelli E, Rostomyan L, Defilles C, Angelini M, Oliva MA, Ceccato F, Maiorani O, Daly AF, Esposito V, Buttarelli F, Figarella-Branger D, Giangaspero F, Spada A, Scaroni C, Aesse E, Beckers A (2013) Somatostatin analogues increase AIP expression in somatotropinomas, irrespective of Gsp mutations. Endocr Relat Cancer 20:753-766. doi:10.1530/ERC-12-0322

30. Chahal HS, Trivellin G, Leontiou CA, Alband N, Fowkes RC, Tahir A, Igreja SC, Chapple JP, Jordan S, Lupp A, Schulz S, Ansorge O, Karavitaki N, Carlsen E, Wass JA, Grossman AB, Korbonits M (2012) Somatostatin analogs modulate AIP in somatotroph adenomas: the role of the ZAC1 pathway. J Clin Endocrinol Metab 97(8):E1411-E1420. doi:10.1210/ jc.2012-1111

31. Tuominen I, Heliovaara E, Raitila A, Rautiainen MR, Mehine M, Katainen R, Donner I, Aittomaki V, Lehtonen HJ, Ahlsten M, Kivipelto L, Schalin-Jantti C, Arola J, Hautaniemi S, Karhu A (2015) AIP inactivation leads to pituitary tumorigenesis through defective Galphai-cAMP signaling. Oncogene 34(9):1174-1184. doi:10.1038/onc. 2014.50

32. Formosa R, Xuereb-Anastasi A, Vassallo J (2013) Aip regulates cAMP signalling and GH secretion in GH3 cells. Endocr Relat Cancer 20(4):495-505. doi:10.1530/ERC-13-0043

33. Bolger GB, Bizzi MF, Pinheiro SV, Trivellin G, Smoot L, Accavitti MA, Korbonits M, Ribeiro-Oliveira A Jr (2016) cAMPspecific PDE4 phosphodiesterases and AIP in the pathogenesis of pituitary tumors. Endocr Relat Cancer 23(5):419-431. doi:10.1530/ERC-15-0205

34. Bolger GB, Peden AH, Steele MR, MacKenzie C, McEwan DG, Wallace DA, Huston E, Baillie GS, Houslay MD (2003) Attenuation of the activity of the cAMP-specific 
phosphodiesterase PDE4A5 by interaction with the immunophilin XAP2. J Biol Chem 278(35):33351-33363

35. Daly AF, Beckers A (2015) Familial isolated pituitary adenomas (FIPA) and mutations in the aryl hydrocarbon receptor interacting protein (AIP) gene. Endocrinol Metab Clin North Am 44(1):19-25. doi:10.1016/j.ecl.2014.10.002

36. Hernández-Ramírez LC, Martucci F, Morgan RM, Trivellin G, Tilley D, Ramos-Guajardo N, Iacovazzo D, D'Acquisto F, Prodromou C, Korbonits M (2016) Rapid proteasomal degradation of mutant proteins is the primary mechanism leading to tumorigenesis in patients with missense AIP mutations. J Clin Endocrinol Metab 101(8):3144-3154. doi:10.1210/jc.2016-1307

37. Preda V, Korbonits M, Cudlip S, Karavitaki N, Grossman AB (2014) Low rate of germline AIP mutations in patients with apparently sporadic pituitary adenomas before the age of 40: a single-centre adult cohort. Eur J Endocrinol 171(5):659-666. doi:10.1530/EJE-14-0426

38. Ferrau F, Romeo PD, Puglisi S, Ragonese M, Torre ML, Scaroni C, Occhi G, De Menis E, Arnaldi G, Trimarchi F, Cannavo, S (2016) Analysis of GPR101 and AIP genes mutations in acromegaly: a multicentric study. Endocr. doi:10.1007/ s12020-016-0862-4

39. Tichomirowa MA, Barlier A, Daly AF, Jaffrain-Rea ML, Ronchi CL, Yaneva M, Urban JD, Petrossians P, Elenkova AP, Tabarin A, Desailloud R, Maiter D, Schurmeyer T, Cozzi R, Theodoropoulou M, Sievers C, Bernabeu I, Naves LA, Chabre O, Fajardo MC, Hana V, Halaby G, Delemer B, Labarta JI, Sonnet E, Ferrandez A, Hagelstein MT, Caron P, Stalla GK, Bours V, Zacharieva S, Spada A, Brue T, Beckers A (2011) High prevalence of AIP gene mutations following focused screening in young patients with sporadic pituitary macroadenomas. Eur J Endocrinol 165(4):509-515. doi:10.1530/ EJE-11-0304

40. Cazabat L, Bouligand J, Salenave S, Bernier M, Gaillard S, Parker F, Young J, Guiochon-Mantel A, Chanson P (2012) Germline AIP mutations in apparently sporadic pituitary adenomas: prevalence in a prospective single-center cohort of 443 patients. J Clin Endocrinol Metab 97(4):E663-E670. doi:10.1210/ jc.2011-2291

41. Cuny T, Pertuit M, Sahnoun-Fathallah M, Daly AF, Occhi G, Odou MF, Tabarin A, Nunes ML, Delemer B, Rohmer V, Desailloud R, Kerlan V, Chabre O, Sadoul JL, Cogne M, Caron P, Cortet C, Lienhardt-Roussie A, Raingeard I, Guedj AM, Brue T, Beckers A, Weryha G, Enjalbert A, Barlier A (2013) Genetic analysis in young patients with sporadic pituitary macroadenomas:Beside AIP don't forget MEN1 genetic analysis. Eur J Endocrinol 168:533-541. doi:10.1530/EJE-12-0763

42. Stratakis CA, Tichomirowa MA, Boikos S, Azevedo MF, Lodish M, Martari M, Verma S, Daly AF, Raygada M, Keil MF, Papademetriou J, Drori-Herishanu L, Horvath A, Tsang KM, Nesterova M, Franklin S, Vanbellinghen JF, Bours V, Salvatori R, Beckers A (2010) The role of germline AIP, MEN1, PRKAR1A, CDKN1B and CDKN2C mutations in causing pituitary adenomas in a large cohort of children, adolescents, and patients with genetic syndromes. Clin Genet 78(5):457-463

43. Ramirez-Renteria C, Hernandez-Ramirez LC, Portocarrero-Ortiz L, Vargas G, Melgar V, Espinosa E, Espinosa-de-Los-Monteros AL, Sosa E, Gonzalez B, Zuniga S, Unterlander M, Burger J, Stals K, Bussell AM, Ellard S, Dang M, Iacovazzo D, Kapur S, Gabrovska P, Radian S, Roncaroli F, Korbonits M, Mercado M (2016) AIP mutations in young patients with acromegaly and the Tampico Giant: the Mexican experience. Endocr 53(2):402-411. doi:10.1007/s12020-016-0930-9

44. Korbonits M, Storr H, Kumar AV (2012) Familial pituitary adenomas: who should be tested for AIP mutations? Clin Endocrinol 77(3):351-356. doi:10.1111/j.1365-2265.2012.04445.x
45. Daly AF, Yuan B, Fina F, Caberg JH, Trivellin G, Rostomyan L, de Herder WW, Naves LA, Metzger D, Cuny T, Rabl W, Shah N, Jaffrain-Rea ML, Zatelli MC, Faucz FR, Castermans E, Nanni-Metellus I, Lodish M, Muhammad A, Palmeira L, Potorac I, Mantovani G, Neggers SJ, Klein M, Barlier A, Liu P, Ouafik L, Bours V, Lupski JR, Stratakis CA, Beckers A (2016) Somatic mosaicism underlies X-linked acrogigantism syndrome in sporadic male subjects. Endocr Relat Cancer 23(4):221-233. doi:10.1530/ERC-16-0082

46. Naves LA, Daly AF, Dias LA, Yuan B, Zakir JC, Barra GB, Palmeira L, Villa C, Trivellin G, Junior AJ, Neto FF, Liu P, Pellegata NS, Stratakis CA, Lupski JR, Beckers A (2016) Aggressive tumor growth and clinical evolution in a patient with X-linked acro-gigantism syndrome. Endocr 51(2):236-244. doi:10.1007/ s12020-015-0804-6

47. Gordon RJ, Bell J, Chung WK, David R, Oberfield SE, Wardlaw SL (2016) Childhood acromegaly due to X-linked acrogigantism: long term follow-up. Pituitary 19(6):560-564. doi:10.1007/ s11102-016-0743-0

48. Rodd C, Millette M, Iacovazzo D, Stiles CE, Barry S, Evanson J, Albrecht S, Caswell R, Bunce B, Jose S, Trouillas J, Roncaroli F, Sampson J, Ellard S, Korbonits M (2016) Somatic GPR101 duplication causing X-linked acrogigantism (XLAG)-diagnosis and management. J Clin Endocrinol Metab 101(5):1927-1930. doi:10.1210/jc.2015-4366

49. Lecoq AL, Bouligand J, Hage M, Cazabat L, Salenave S, Linglart A, Young J, Guiochon-Mantel A, Chanson P, Kamenicky P (2016) Very low frequency of germline GPR101 genetic variation and no biallelic defects with AIP in a large cohort of patients with sporadic pituitary adenomas. Eur J Endocrinol 174(4):523-530. doi:10.1530/EJE-15-1044

50. Kamenicky P, Bouligand J, Chanson P (2015) Gigantism, acromegaly, and GPR101 mutations. N Engl J Med 372(13), 1264. doi:10.1056/NEJMc1500340\#SA1

51. Concolino P, Costella A, Capoluongo E (2016) Multiple endocrine neoplasia type 1 (MEN1): An update of 208 new germline variants reported in the last nine years. Cancer Genet 209(12):36-41. doi:10.1016/j.cancergen.2015.12.002

52. Lemos MC, Thakker RV (2008) Multiple endocrine neoplasia type 1 (MEN1): analysis of 1336 mutations reported in the first decade following identification of the gene. Hum Mutat 29(1):22-32. doi:10.1002/humu.20605

53. Goudet P, Dalac A, Le Bras M, Cardot-Bauters C, Niccoli P, Levy-Bohbot N, du Boullay H, Bertagna X, Ruszniewski P, Borson-Chazot F, Verges B, Sadoul JL, Menegaux F, Tabarin A, Kuhn JM, d'Anella P, Chabre O, Christin-Maitre S, Cadiot G, Binquet C, Delemer, B (2015) MEN1 disease occurring before 21 years old: a 160-patient cohort study from the Groupe d'etude des Tumeurs Endocrines. J Clin Endocrinol Metab 100(4):15681577. doi:10.1210/jc.2014-3659

54. Goudet P, Bonithon-Kopp C, Murat A, Ruszniewski P, Niccoli P, Menegaux F, Chabrier G, Borson-Chazot F, Tabarin A, Bouchard P, Cadiot G, Beckers A, Guilhem I, Chabre O, Caron P, Du Boullay H, Verges B, Cardot-Bauters, C (2011) Genderrelated differences in MEN1 lesion occurrence and diagnosis: a cohort study of 734 cases from the Groupe d'etude des Tumeurs Endocrines. Eur J Endocrinol 165(1):97-105. doi:10.1530/ EJE-10-0950

55. Borson-Chazot F, Garby L, Raverot G, Claustrat F, Raverot V, Sassolas G (2012) Acromegaly induced by ectopic secretion of GHRH: a review 30 years after GHRH discovery. Ann Endocrinol (Paris) 73(6):497-502. doi:10.1016/j.ando.2012.09.004

56. Garby L, Caron P, Claustrat F, Chanson P, Tabarin A, Rohmer V, Arnault G, Bonnet F, Chabre O, Christin-Maitre S, du-Boullay H, Murat A, Nakib I, Sadoul JL, Sassolas G, Claustrat B, Raverot G, Borson-Chazot F (2012) Clinical characteristics and outcome 
of acromegaly induced by ectopic secretion of growth hormonereleasing hormone $(\mathrm{GHRH})$ : a French nationwide series of 21 cases. J Clin Endocrinol Metab 97(6):2093-2104. doi:10.1210/ jc.2011-2930

57. Marini F, Giusti F, Brandi ML (2015) Genetic test in multiple endocrine neoplasia type 1 syndrome: an evolving story. World. J Exp Med 5(2):124-129. doi:10.5493/wjem.v5.i2.124

58. Thakker RV, Newey PJ, Walls GV, Bilezikian J, Dralle H, Ebeling PR, Melmed S, Sakurai A, Tonelli F, Brandi ML (2012) Clinical practice guidelines for multiple endocrine neoplasia type 1 (MEN1). J Clin Endocrinol Metab 97(9):2990-3011. doi:10.1210/jc.2012-1230

59. Agarwal SK, Mateo CM, Marx SJ (2009) Rare germline mutations in cyclin-dependent kinase inhibitor genes in multiple endocrine neoplasia type 1 and related states. J Clin Endocrinol Metab 94(5):1826-1834. doi:10.1210/jc.2008-2083

60. Kirschner LS, Carney JA, Pack SD, Taymans SE, Giatzakis C, Cho YS, Cho-Chung YS, Stratakis CA (2000) Mutations of the gene encoding the protein kinase A type I-alpha regulatory subunit in patients with the Carney complex. Nat Genet 26(1):89-92. doi: $10.1038 / 79238$

61. Horvath A, Faucz F, Finkielstain GP, Nikita ME, Rothenbuhler A, Almeida M, Mericq V, Stratakis CA (2010) Haplotype analysis of the promoter region of phosphodiesterase type $8 \mathrm{~B}$ (PDE8B) in correlation with inactivating PDE8B mutation and the serum thyroid-stimulating hormone levels. Thyroid 20(4):363-367. doi:10.1089/thy.2009.0260

62. Forlino A, Vetro A, Garavelli L, Ciccone R, London E, Stratakis CA, Zuffardi O (2014) PRKACB and Carney complex. N Engl J Med 370(11):1065-1067. doi:10.1056/NEJMc1309730

63. Iversen K.: Acromegaly associated with phaeochromocytoma. Acta Med Scand. 142, 1-5(1952)

64. Xekouki P, Szarek E, Bullova P, Giubellino A, Quezado M, Mastroyannis SA, Mastorakos P, Wassif CA, Raygada M, Rentia N, Dye L, Cougnoux A, Koziol D, Sierra Mde L, Lyssikatos C, Belyavskaya E, Malchoff C, Moline J, Eng C, Maher LJ 3rd, Pacak K, Lodish M, Stratakis CA (2015) Pituitary adenoma with paraganglioma/pheochromocytoma (3PAs) and succinate dehydrogenase defects in humans and mice. J Clin Endocrinol Metab 100(5):E710-E719. doi:10.1210/jc.2014-4297

65. Dénes J, Swords F, Rattenberry E, Stals K, Owens M, Cranston T, Xekouki P, Moran L, Kumar A, Wassif C, Fersht N, Baldeweg SE, Morris D, Lightman S, Agha A, Rees A, Grieve J, Powell M, Boguszewski CL, Dutta P, Thakker RV, Srirangalingam U, Thompson CJ, Druce M, Higham C, Davis J, Eeles R, Stevenson M, O'Sullivan B, Taniere P, Skordilis K, Gabrovska P, Barlier A, Webb SM, Aulinas A, Drake WM, Bevan JS, Preda C, Dalantaeva N, Ribeiro-Oliveira A Jr, Tena GI, Yordanova G, Iotova V, Evanson J, Grossman AB, Trouillas J, Ellard S, Stratakis CA, Maher ER, Roncaroli F, Korbonits M (2015) Heterogeneous genetic background of the association of pheochromocytoma/paraganglioma and pituitary adenoma: results from a large patient cohort. J Clin Endocrinol Metab 100:E531-E541. doi:10.1210/jc.2014-3399

66. Benn DE, Gimenez-Roqueplo AP, Reilly JR, Bertherat J, Burgess J, Byth K, Croxson M, Dahia PL, Elston M, Gimm O, Henley D, Herman P, Murday V, Niccoli-Sire P, Pasieka JL, Rohmer V, Tucker K, Jeunemaitre X, Marsh DJ, Plouin PF, Robinson BG (2006) Clinical presentation and penetrance of pheochromocytoma/paraganglioma syndromes. J Clin Endocrinol Metab 91(3):827-836. doi:10.1210/jc.2005-1862

67. Brahma, A., Heyburn, P., Swords, F (2009) Familial prolactinoma occuring in association with SDHB mutation positive paraganglioma. In: Endocrine Abstracts Spring, p. P239

68. Xekouki P, Pacak K, Almeida M, Wassif CA, Rustin P, Nesterova M, de la Luz Sierra M, Matro J, Ball E, Azevedo M,
Horvath A, Lyssikatos C, Quezado M, Patronas N, Ferrando B, Pasini B, Lytras A, Tolis G, Stratakis CA (2012) Succinate dehydrogenase (SDH) D subunit (SDHD) inactivation in a growth-hormone-producing pituitary tumor: a new association for SDH? J Clin Endocrinol Metab 97(3):E357-E366. doi:10.1210/jc.2011-1179

69. Papathomas TG, Gaal J, Corssmit EP, Oudijk L, Korpershoek E, Heimdal K, Bayley JP, Morreau H, van Dooren M, Papaspyrou K, Schreiner T, Hansen T, Andresen PA, Restuccia DF, van Kessel I, van Leenders GJ, Kros JM, Looijenga LH, Hofland LJ, Mann W, van Nederveen FH, Mete O, Asa SL, de Krijger RR, Dinjens WN (2014) Non-pheochromocytoma (PCC)/paraganglioma (PGL) tumors in patients with succinate dehydrogenase-related PCC-PGL syndromes: a clinicopathological and molecular analysis. Eur J Endocrinol 170(1):1-12. doi:10.1530/ EJE-13-0623

70. Heinlen JE, Buethe DD, Culkin DJ, Slobodov G (2011) Multiple endocrine neoplasia $2 \mathrm{a}$ presenting with pheochromocytoma and pituitary macroadenoma. ISRN Oncol. doi:10.5402/2011/732452

71. Weinstein LS, Shenker A, Gejman PV, Merino MJ, Friedman E, Spiegel AM (1991) Activating mutations of the stimulatory $\mathrm{G}$ protein in the McCune-Albright syndrome. N Engl J Med 325(24):1688-1695. doi:10.1056/NEJM199112123252403

72. Salpea P, Stratakis CA (2014) Carney complex and McCune Albright syndrome: an overview of clinical manifestations and human molecular genetics. Mol Cell Endocrinol 386(1-2):8591. doi:10.1016/j.mce.2013.08.022

73. Gadelha MR, Trivellin G, Hernández-Ramírez LC, Korbonits M (2013) Genetics of pituitary adenomas. Front Horm Res 41:111140. doi:10.1159/000345673

74. Barlier A, Gunz G, Zamora AJ, Morange-Ramos I, FigarellaBranger D, Dufour H, Enjalbert A, Jaquet P (1998) Pronostic and therapeutic consequences of Gs alpha mutations in somatotroph adenomas. J Clin Endocrinol Metab 83(5):1604-1610

75. Efstathiadou ZA, Bargiota A, Chrisoulidou A, Kanakis G, Papanastasiou L, Theodoropoulou A, Tigas SK, Vassiliadi DA, Alevizaki M, Tsagarakis S (2015) Impact of gsp mutations in somatotroph pituitary adenomas on growth hormone response to somatostatin analogs: a meta-analysis. Pituitary 18(6):861-867. doi:10.1007/s11102-015-0662-5

76. Landis CA, Masters SB, Spada A, Pace AM, Bourne HR, Vallar L (1989) GTPase inhibiting mutations activate the a chain of Gs and stimulate adenylyl cyclase in human pituitary tumors. Nature 340:692-696

77. Josefson J, Listernick R, Fangusaro JR, Charrow J, Habiby R (2011) Growth hormone excess in children with neurofibromatosis type 1-associated and sporadic optic pathway tumors. J Pediatr 158(3):433-436. doi:10.1016/j.jpeds.2010.09.013

78. Checa Garrido A, del Pozo Pico C (2013) Acromegaly and type 1 neurofibromatosis. Is association of both conditions due to chance? Endocrinol Nutr 60(3):144-145. doi:10.1016/j. endonu.2012.01.020

79. Hannah-Shmouni F, Trivellin G, Stratakis CA (2016) Genetics of gigantism and acromegaly. Growth Horm IGF Res 30-31:3741. doi:10.1016/j.ghir.2016.08.002

80. Bizzarri C, Bottaro G (2015) Endocrine implications of neurofibromatosis 1 in childhood. Horm Res Paediatr 83(4):232-241. doi:10.1159/000369802

81. Taboada GF, Tabet AL, Naves LA, de Carvalho DP, Gadelha MR (2009) Prevalence of gsp oncogene in somatotropinomas and clinically non-functioning pituitary adenomas: our experience. Pituitary 12(3):165-169. doi:10.1007/s11102-008-0136-0

82. Yoshimoto K, Iwahana H, Fukuda A, Sano T, Itakura M (1993) Rare mutations of the Gs alpha subunit gene in human endocrine tumors. Mutation detection by polymerase chain reactionprimer-introduced restriction analysis. Cancer 72(4):1386-1393 
83. Song ZJ, Reitman ZJ, Ma ZY, Chen JH, Zhang QL, Shou XF, Huang CX, Wang YF, Li SQ, Mao Y, Zhou LF, Lian BF, Yan H, Shi YY, Zhao Y (2016) The genome-wide mutational landscape of pituitary adenomas. Cell Res. doi:10.1038/cr.2016.114

84. Fougner SL, Casar-Borota O, Heck A, Berg JP, Bollerslev J (2012) Adenoma granulation pattern correlates with clinical variables and effect of somatostatin analogue treatment in a large series of patients with acromegaly. Clin Endocrinol 76(1):96102. doi:10.1111/j.1365-2265.2011.04163.x

85. Buchfelder M, Fahlbusch R, Merz T, Symowski H, Adams EF (1999) Clinical correlates in acromegalic patients with pituitary tumors expressing GSP oncogenes. Pituitary 1(3-4):181-185

86. Ronchi CL, Peverelli E, Herterich S, Weigand I, Mantovani G, Schwarzmayr T, Sbiera S, Allolio B, Honegger J, Appenzeller
S, Lania AG, Reincke M, Calebiro D, Spada A, Buchfelder M, Flitsch J, Strom TM, Fassnacht M (2016) Landscape of somatic mutations in sporadic GH-secreting pituitary adenomas. Eur $\mathbf{J}$ Endocrinol 174(3):363-372. doi:10.1530/EJE-15-1064

87. Valimaki N, Demir H, Pitkanen E, Kaasinen E, Karppinen A, Kivipelto L, Schalin-Jantti C, Aaltonen LA, Karhu A (2015) Whole-genome sequencing of growth hormone $(\mathrm{GH})$-secreting pituitary adenomas. J Clin Endocrinol Metab 100(10):39183927. doi:10.1210/jc.2015-3129

88. Strunnikov A (2013) Cohesin complexes with a potential to link mammalian meiosis to cancer. Cell Regen 2(1):4. doi:10.1186/2045-9769-2-4 